\title{
PROBLEMS OF THE SMALL FARM
}

$\mathrm{T}$ HE three papers covering the problems of the small farm, given at Belfast on September 8 to Section M (Agriculture) of the British Association, differed in scope so widely that it was difficult at first to see how they fitted together ; but on examination, it was possible to see a pattern which at least indicated some of the problems facing small farmers in the United Kingdom, without providing a ready-made solution for them.

Mr. Ronald Ede, agricultural attaché for Denmark, described the agricultural system in Scandinavia and the Low Countries. This account was particularly interesting because, although the average size of farm holdings in these countries is well below that of Great Britain, it is an accepted fact that the farming efficiency is high, and high-quality farm produce is exported at competitive prices in the world market. The second speaker, Mr. A. Cromie, a farmer in Northern Ireland, described his own farm-a typical small one in a country where the average size of farm is small-and gave his views on the problems facing farmers such as himself. The importance of his paper lay in the fact that he is a very progressive farmer. Finally, Mr. W. H. Cashmore, director of the National Institute of Agricultural Engineering, Silsoe, related the problems of mechanization to the size and type of farm and suggested that attention to organization, careful selection of equipment and further work on farming techniques would play their parts in extending the benefits of mechanization to the smaller farms.

In describing Scandinavian agriculture, Mr. Ede stated that nearly all land is owned by the farmers, but there is rigid government control of the size of small-holdings. Although the minimum size is five acres, the average is less than forty acres, and the tendency during the past thirty years has been to reduce both the number of large and small farms, and so raise the number of farms of average size, amalgamation of farms being prohibited. The labour is mostly family labour, and the majority of farms run on a mortgage at a low rate of interest. A smallholder with $£ 250$-500 capital can borrow up to $£ 3,200$, and the average level of borrowing is about $£ 1,300$.

The standard of living on the Danish farm is low compared with that in Britain, and smallholders are not replacing themselves because of the difficulties of finance. Many of the sons of smallholders move into industrial employment, the keenest demand for small farms coming from the sons of the medium-sized farms.

There is no State advisory service in Denmark, but advice reaches the farmers through the Smallholders' Association. Mr. Ede did not mention anything of special note about the cropping, except that there is a marked increase in fodder beet and a steady rise in fruit growing. The larger farms tend to grow the cereals for feeding-stuffs, and on the smallholdings grassland predominates.

Some machines, particularly the special and expensive implements, are handled on a co-operative basis. The standard of machinery at the homestead for handling cattle-food is high. The main features of Danish smallholdings are: small acreage (by British standards), good buildings that are well equipped, and dependence on borrowed capital. Even in Denmark there is some concern about the level of borrowed money, and it is realized that a fall in world prices would cause difficulties. In the dis- cussion on this paper the mortgage position was the main topic. The general opinion was that the amount borrowed was high and, while it might be sound policy to raise money for current expenditure, it was risky to use borrowed capital for such items as machinery and buildings.

Mr. Cromie's farm is $37 \frac{1}{2}$ acres, of which $29 \frac{1}{2}$ is arable, and he rents a further 34 acres. His cropping is varied and includes small acreages of fodder crops such as marrow stem kale, fodder beet and arable silage; he also grows cash crops such as potatoes, ryegrass and oats, for seed.

The livestock consists of twelve Friesian cows and their followers, five sows and all their progeny, plus thirty to forty extra pigs each year, and some poultry. It was obvious that his stocking and production was well above average. The following examples illustrate the planning to raise the total output: the tractor had been equipped to do all the work, to the total exclusion of horses, thereby making it possible to carry two more cows; an analysis of the soil from various parts of the farm had indicated deficiencies which, when corrected, made it possible to carry more stock with an appreciable increase in the milk yield; a proportion of the grassland is ploughed out and reseeded each year to keep up the quality of the grass ; silage-making is practised to conserve grass ; and an electric ferice is used for strip or controlled grazing.

Mr. Cromie confirmed the view that the production per acre can be higher on a small farm than a larger one because of greater personal attention and super vision. He was convinced that the output could be increased by 100 per cent if the results of agricultural science could be put into practice. At the present time a good deal of scientific work does not reach the small farmer. Quite often, improved techniques required additional capital outlay, and Mr. Cromie stated that the greatest handicap to progress was the large amount of capital needed, especially for reconstruction of buildings.

Great interest was aroused by the statement that the standard of knowledge on the farm will have to be raised. In the discussion, Mr. Cromie explained that farmers are taking an increasing interest in the management of a farm and the application of scientific work, but that the farmer is often too tired at night to go to lectures, discussions, etc., after a long day of toil. He thought that there is need for greater effort in spreading knowledge of scientific and experi mental work, and suggested that demonstration farms would help.

Mr. Cromie confirmed that a farmer and his wife can make a fair living from about thirty-five acres in Northern Ireland, but he himself was strongly in favour of extending the area farmed by a further thirty acres; this justifies the services of a hired man and makes possible an increase in livestock. He admitted that in practice the high rental of the extra land and the labour cost offset most, if not all, the extra income.

In the discussion it was suggested that specialization on a few crops might increase the overall output per acre, and the idea of installing a small grass-drier to provide concentrated food for the dairy cattle and for sale was put forward. The case against 100 per cent grassland on the small farm is that arable land helps to keep the farm clean, and provides some cash 
crops such as potatoes and seed corn as well as by-products for livestock.

Mr. Cromie is without mains electricity, which is essential for a highly mechanized dairy and many of the appliances which support a 100 per cent grassland farm. In considering how far the use of machinery could assist the small farm, Mr. Cashmore stated that as the size of farm decreases below two hundred acres there is a marked upward trend in the capital invested in machinery per acre. His paper dealt with farms in the 50-150 acres class, on the assumption that below this level some specialization in cropping was necessary and so was outside the scope of this paper.

An analysis of capital invested in machinery and annual cash returns indicates that the greater use of machinery raises the yield rather than replaces regular labour. The margin of profit from increased mechanization is slender and very dependent on sound organization and proper maintenance. Even in the 50-150 acres class, capital expenditure on machinery increases as the size of holding decreases, but is justified by the higher returns per acre due to personal supervision and attention to detail.

In discussing how far expenditure on machinery could be kept down, Mr. Cashmore quoted from field surveys and investigations to show that in a number of cases the main advantage of a specialized machine is that it enables men to work a long day without undue fatigue. For short periods there is a slightly higher demand for labour ; but the overall cost of the operation is no higher. On these grounds it could be argued that the small farm would gain nothing by purchasing these machines. The limitations of the co-operative use of machinery were stated; but where suitable contractor service is not available, there are possibilities in local farmers' co-operative societies for the use of certain expensive equipment. This system is already being employed in England for cereal harvesting and grass drying, and might be extended to ditching, hedge cutting, dung loading, etc.

Considerable emphasis was placed on better techniques and improved organization, and investigations were quoted to show that the efficiency of organization has a greater effect on the cost of a process than the design of the equipment. Commenting on general design, Mr. Cashmore stated that the small farm does not require scaled-down tractors or implements except in the case of barn machinery, which can be designed to run automatically provided electricity is available and the buildings are in good order. Already satisfactory equipment for the small farm has been devised, examples being milking machines and platform grain driers. It is possible that many more modifications or new developments would be helpful, but these must be related to technique investigations.

The discussion supported these views and emphasized the need for detailed studies to reveal whether the various problems could be solved by improved techniques, improvisation or new machines. It was thought that on the small farms the field equipment would have to be kept as simple as possible, with marked development of machinery for handling cattle food at the homestead.

In conclusion, the problems facing the small farmers are : shortage of capital, lack of knowledge on scientific work, poor farm buildings, and, in some cases, the wrong machinery. All these problems are interrelated, and, provided the size of holding is not less than 50-75 acres for general farming, it is reasonable to expect progress in the future.

$$
\text { W. H. CASHMORE }
$$

\section{CHEMISTRY IN ABERDEEN}

\author{
BY PROF. R. M. BARRER
}

CHEMISTRY was one of the first sciences to 1 develop as a university study. In part for this reason, but still more because of its intrinsic interest and great practical value, the subject now attracts many students. University departments, often designed long ago to house smaller numbers, have in many centres become inadequate and outmoded. It is a feature of recent university development in Britain that serious efforts are being made to remedy this situation by rebuilding or by rehabilitating and extending existing chemistry departments. In Aberdeen, the University is now seeing the completion of a building first contemplated more than thirty years ago, and commenced in January 1949. The subject of chemistry has been removed from Marischal College, where it had been taught since the union of the two original Universities of Aberdeen in 1860, and has been rehoused on a site near the historic buildings of King's College. The new building was opened by Sir Robert Robinson on September 17. The newness of the department may render a brief description of the layout and facilities of interest to scientists and others concerned in the design of science departments.

The building has been constructed in the form of a cross. Four floors are devoted to chemistry, and a final floor to soil science and agricultural biochemistry, both subjects closely allied to chemistry and of considerable significance to the rich agricultural industry of Aberdeenshire. Each is under a separate head. All floors are served by a central staircase, and by subsidiary stairs at the end of the south wing. In addition, the building contains two lifts, of which one is designed for carrying goods and equipment. The building is a granite structure, the granite of several blending hues having been taken from six different quarries.

The lower ground floor of the building contains the main chemical and apparatus stores; mechanical, glassblowing and electronic workshops; a refrigerated room operating at adjustable temperatures down to $-10^{\circ}$; and the electron microscope. There is in addition some research accommodation on this floor. In the east wing of the ground floor is situated the large elementary chemistry laboratory, with two balance rooms, one at each end. Associated preparation and subsidiary store rooms run into the south wing, which also contains research and staff rooms and a lecture room. This room is served by a large preparation room which also serves the main lecture theatre in the west wing. The theatre is excellently appointed and holds about 220 students. In the north wing are the main entrance hall, and large cloakrooms. Additional cloakrooms are available on every floor.

The first floor houses in the east wing the inorganic teaching laboratory with associated preparation and balance rooms. There is also a room especially provided for electrochemical work, and an inorganic research laboratory. In the west wing is a large research laboratory, and in the north wing a laboratory specially designed for larger scale chemical and physico-chemical operations. There is fume extraction from this room, which can be general or else can be concentrated at any desired point. In the same wing are a departmental library and staff room and further research laboratories. The south 